\title{
Effects of Competency-based Instructional Design of Indoor Gardening Course on Job Performance for University Students with Disabilities
}

\author{
Soo Yeon Kim* \\ Dept. of Rehabilitation Independence, Korea Nazarene University, Cheonan 456, South Korea
}

\begin{abstract}
This study aimed to improve job performance for student with disabilities through competency-based instructionally designed indoor gardening course. In this study, The first step is that job analysis such as task range, eligibility, core competency, index of capability, etc was done by a focus group composed of 10 specialists in the industry and academia. The second step is developing a diagnostic tool of indoor gardening activity competency. The third step is the selection of diagnostic test students. The 4 th step is selection of subjects for competency diagnostic testing. The 5th step is competency diagnostic testing The 6th step is analysis of competency improvement for instructional design. In result, average of cognitive competency improved from 1.80 to 3.96, physical competency from 1.86 points to 4.06 points and social competency from 2.30 points to 4.40 points after 15 weeks course. We found that effect of indoor gardening instructional design on job competency improvement. The next step is the establishment of instruction guidelines for indoor garden assistant manager or all kind of assistant job as university students with disabilities.
\end{abstract}

Keywords: analysis, capacity, diagnostic test, improvement

\section{Introduction}

University education has been merely in the form of a catalogue or a list of courses to earn the credits required for graduation. Recently there has been a perspective that this paradigm must be shifted so that the completion of job performance required by each department or major leads to graduation, which resulted in the recent reform of university education into competency-based curriculum (Kim et al., 2002). Thus, this concept must be applied also to the curriculum for increasing university students with developmental disabilities (Song, 2004), and it is necessary to systematically manage the quality of such curriculum. Accordingly, this study will redesign the indoor gardening subject for developmental disabilities with focus on competency so that it meets the realistic needs of completing job performance, develop a job competency diagnostic evaluation tool and analyze the effects of competency-based instructional design on job competency of university students with disabilities. This is an approach with the research question of how competency-based courses affect improvement of job performance of university students with developmental disabilities compared to the conventional

This Research was supported by the Korea Nazarene University Research Grants in 2017.

Received: November 29, 2017, Revised: December 7, 2017, Accepted: December 14, 2017

*Comesponding author:ksy0713@kornu.ac.kr 
theory-based courses. This analytic data may be a significant resource for promoting horticultural education as a regular curriculum for increasing university students with developmental disabilities. Meanwhile, with the enactment of the Act on Guarantee of Rights of and Support for Persons with Developmental Disabilities (enacted in November 2015), the college entrance rate of people with developmental disabilities has been increasing, which makes this study well-timed. Furthermore, while horticultural education for people with developmental disabilities had been non-academic, this study made the gardening course be used as basic data to design a competency-based class organically related to the core competency of the entire university when used in regular curriculum for developmental disabilities in the university. Thus, the ultimate goal is to promote the field of horticulture in university education for students with developmental disabilities.

\section{Research Method}

\section{Organization of an expert panel}

Educators with experience in university education for students with developmental disabilities and horticulture-related field specialists were selected as members of the focus group, or expert panel. Horticultural specialists were selected among those involved in horticultural therapy, floral design, indoor gardening, and botanical garden management, and the panel for competency-based horticultural education was organized with 10 specialists with at least 5 years of field experience among vocational rehabilitation specialists with experience in using horticultural programs in a welfare center for the disabled as well as professors of special education and vocational rehabilitation.

\section{Competency-based instructional design}

\section{Step 1. Definition of task related to the course}

Step 1 of instructional design is defining task deriving from the indoor gardening course. The number of employees in the structure of employment was searched on Q-net in connection with indoor gardening assistant, and the current state of jobs in Korea Employment Agency for the Disabled was analyzed. Then, through the contents covered in the indoor gardening course the DACUM technique was used as in the study by Kim (2016) so that students can later be employed as

Table 1. Focus group position.

\begin{tabular}{lccll}
\hline Name & Career $(\mathrm{yr})$ & Age & Sex & \multicolumn{1}{c}{ Position (Major) } \\
\hline Kim00 & 20 & 53 & Female & Professor of horticulture rehabilitation \\
Yoo00 & 20 & 59 & Female & Professor of special education \\
Kim00 & 20 & 62 & Female & Professor of floriculture \\
Kim00 & 10 & 55 & Male & Professor of rehabilitation \\
Kim00 & 5 & 45 & Male & Professor of rehabilitation \\
Park00 & 8 & 48 & Female & Specialist of horticulture \\
Kim00 & 8 & 48 & Female & Specialist of rehabilitation \\
Hwang00 & 5 & 28 & Female & Specialist of horticulture \\
Choi00 & 6 & 50 & Female & Specialist of rehabilitation \\
Park00 & 6 & 28 & Female & Specialist of horticulture \\
\hline
\end{tabular}


Table 2. Definition of task for indoor garden assistant manager.

\begin{tabular}{lc}
\hline \multicolumn{1}{c}{ Task } & Definition of task \\
\hline Using a tool & using a tools for gardening \\
Delivery & delivering and transporting of gardening product \\
Arrangement & arranging gardening materials \\
Caring & taking care of plants \\
Service & providing interactive services though gardening program \\
\hline
\end{tabular}

indoor gardening assistants of national, public and private botanical gardens. Jobs of indoor gardening assistants were defined upon deliberation in the FGI (focus group interview) of the panel, which were 'using tools,' 'delivering and transporting,' 'arranging things,' 'taking care of plants,' and 'providing interactive services.'

\section{Step 2. Selection of core competencies and capability indicators}

Step 2 first reviews the core competencies of the departments specialized in developmental disabilities as the step to select core competencies for the job. Then, it comparatively analyzes the assessment indicators of horticultural activities by mentally challenged people with HAPA (Horticultural Activity Performance Assessment) of Kim (2004), coming up with cognitive, physical and social competencies as core competencies and selecting 'concentration', 'concept of numbers', 'spatial ability', 'ability to use a tool', 'fine motor skill', 'hand-eye coordination', 'communication skill', 'ability to fulfill a duty', 'ability to consider others' as the capability indicators, based on which it defined and described the learning standards in terms of knowledge (K), skill (S) and attitude (A).

\section{Step 3. Development of a competency diagnostic tool}

Step 3 is developing a competency diagnostic tool to analyze the improvement of competency. The reliability of HAPA (Horticultural Activity Performance Assessment) developed by Kim (2004) to assess the performance of horticultural activities by mild and severe mentally challenged people was 0.970 based on Cronbach's $\alpha$ test, which verifies its reliability as an assessment tool. In addition, to select fields that meet the level of students with developmental disabilities in university, the expert panel brainstormed ideas and reviewed and discussed the parts connected to the tasks of indoor gardening assistants among 19 items in cognitive ability, 23 items in physical ability and 13 items in social ability as shown in Table 5 Then, this study revised and improved the result in the learning standard of descriptive rubric fit for the comprehensive skill of university students with developmental disabilities, and then developed a competency diagnostic tool in the form of self-assessment by students with disabilities.

\section{Step 4. Selection of subjects for competency diagnostic testing}

The subjects of this study are 40 students with developmental disabilities attending K University. This study selected 20 students taking the indoor gardening course designed as competency-based as the experimental group, and the other 20 students with developmental disabilities who did not take the course as the control group.

\section{Step 5. Competency diagnostic testing}

The homogeneity was first tested between the two groups in Step 1, and competency diagnosis testing was performed before and after the course in Step 2. The experimental group took the competency diagnostic testing according to the competency-based instructional design consisting of total 15 sessions, once a week. Learners create a learning standard 
with the ability indicators for each competency as knowledge (K), skill (S) and attitude (A), where knowledge represents the definition, concept and principle required to perform the tasks, skill represents the behavioral ability that can be obtained on site when anticipated result can be produced, and attitude represents inner disposition to respond even if it does not come out as an actual behavior (Kim et al., 2014). Using this self-diagnosis questionnaire, the professor of the course faithfully explained the content of the test according to the level of university students with developmental disabilities, after which the pre-diagnosis and post-diagnosis were carried out in Week 2 after the orientation and Week 14 before the final exam in the last week, with the items rated on a 5-point scale. The control group that did not participate in the indoor gardening course also performed the test in the same way.

\section{Step 6. Competency diagnostic analysis}

This study diagnosed and tested the indicators of cognitive, physical and social competencies of the experimental group and control group before and after the competency-based indoor gardening course to verify the improvement of competencies using SPSS PC 13.0, and analyzed the changes in competencies before and after the course with a paired t-test. The significance level was $p<.01$.

\section{Results}

\section{Instructional design}

Work personality of people with intellectual disabilities (Kang, 2005) is characterized by lack of understanding of work

Table 3. The step of Instructional Design.

\begin{tabular}{cc}
\hline Step & Procedure \\
\hline 1 & Definition of task related to the course \\
2 & Selection of core competencies and capability indicators \\
3 & Development of a competency diagnostic tool \\
4 & Selection of subjects for competency diagnostic testing \\
5 & Competency diagnostic testing \\
6 & Competency diagnostic analysis \\
\hline
\end{tabular}

Table 4. Name and definition of the core competency and index of capacity.

\begin{tabular}{|c|c|c|}
\hline Core competency & $\mathrm{No}^{\mathrm{z}}$ & Index of capability \\
\hline \multirow{3}{*}{ Physical competency } & 1 & ability to use fine motor skills and move entire body with flexibility \\
\hline & 2 & ability to perform hand eye coordination \\
\hline & 3 & ability to deliver container \\
\hline \multirow{3}{*}{ Cognitive competency } & 1 & ability to use horticultural tools \\
\hline & 2 & ability to concentrate on work or leader \\
\hline & 3 & ability to calculate \\
\hline \multirow{3}{*}{ Social competency } & 1 & ability to cooperate with others \\
\hline & 2 & ability to communicate with others \\
\hline & 3 & ability to take care of others \\
\hline
\end{tabular}

${ }^{\mathrm{z}} \mathrm{N}$ : Competency Number. 
Table 5. Instructional design for indoor gardening.

\begin{tabular}{|c|c|c|c|c|c|}
\hline Week & Title & Contents & Core competency & No & Index of capability \\
\hline 1 & Orientation & $\begin{array}{l}\text { Introduction } \\
\text { of Subject }\end{array}$ & & & \\
\hline 2 & Plant environment & Light & Cognitive ability & $3^{\mathrm{z}}$ & Competency to calculate \\
\hline \multirow{2}{*}{3} & \multirow{2}{*}{ Plant environment } & \multirow{2}{*}{ Temperature } & Cognitive ability & 2 & Competency to concentrate on work or leader \\
\hline & & & Physical ability & 3 & Competency to deliver gardening product \\
\hline \multirow{2}{*}{4} & \multirow{2}{*}{ Plant environment } & \multirow{2}{*}{$\begin{array}{l}\text { Watering \& } \\
\text { Humidity }\end{array}$} & Cognitive ability & 3 & Competency to calculate \\
\hline & & & Physical ability & 1 & Competency to use finely detail work with hands \\
\hline \multirow{2}{*}{5} & \multirow{2}{*}{ Plant environment } & \multirow{2}{*}{ Air cleaning } & Cognitive ability & 2 & Competency to concentrate on work leader \\
\hline & & & Physical ability & 1 & Competency to use finely detail work with hands \\
\hline \multirow{3}{*}{6} & \multirow{3}{*}{ Plant environment } & \multirow{3}{*}{ Soil } & Cognitive ability & 3 & Competency to calculate \\
\hline & & & Physical ability & 2 & Competency to coordinate of eye and hand \\
\hline & & & Social ability & 1 & Competency to cooperate with others \\
\hline \multirow{3}{*}{7} & \multirow{3}{*}{ Plant environment } & \multirow{3}{*}{ Soil fertilization } & Cognitive ability & 1 & Competency to use horticultural tools \\
\hline & & & Physical ability & 1 & Competency to coordinate of eye and hand \\
\hline & & & Social ability & 2 & Competency to communicate with others \\
\hline 8 & & Mid examination & & & \\
\hline \multirow{3}{*}{9} & \multirow{3}{*}{$\begin{array}{l}\text { Management } \\
\text { system of Plant }\end{array}$} & \multirow{3}{*}{ Repotting } & Cognitive ability & 1 & Competency to use horticultural tools \\
\hline & & & Physical ability & 3 & Competency to deliver gardening product \\
\hline & & & Social ability & 1 & Competency to cooperate with others \\
\hline \multirow{3}{*}{10} & \multirow{3}{*}{$\begin{array}{l}\text { Management } \\
\text { system of plant }\end{array}$} & \multirow{3}{*}{$\begin{array}{l}\text { Indoor home } \\
\text { gardening }\end{array}$} & Cognitive ability & 2 & Competency to concentrate on work \\
\hline & & & Physical ability & 2 & Competency to coordinate of eye and hand \\
\hline & & & Social ability & 3 & Competency to take care others \\
\hline \multirow{3}{*}{11} & \multirow{3}{*}{$\begin{array}{l}\text { Management } \\
\text { system of Plant }\end{array}$} & \multirow{3}{*}{$\begin{array}{l}\text { Indoor office } \\
\text { gardening }\end{array}$} & Cognitive ability & 1 & Competency to use horticultural tools \\
\hline & & & Physical ability & 1 & Competency to use finely detail work with hands \\
\hline & & & Social ability & 3 & Competency to take care others \\
\hline \multirow{3}{*}{12} & \multirow{3}{*}{$\begin{array}{c}\text { Management } \\
\text { system of Plant }\end{array}$} & \multirow{3}{*}{$\begin{array}{c}\text { Botanical garden } \\
\text { management }\end{array}$} & Cognitive ability & 3 & Competency to calculate \\
\hline & & & Physical ability & 2 & Competency to coordinate of eye and hand \\
\hline & & & Social ability & 1 & Competency to cooperate with others \\
\hline \multirow{3}{*}{13} & \multirow{3}{*}{$\begin{array}{l}\text { Management } \\
\text { system of plant }\end{array}$} & & Cognitive ability & 1 & Competency to use horticultural tools \\
\hline & & $\begin{array}{l}\text { Roof garden } \\
\text { management }\end{array}$ & Physical ability & 1 & Competency to use finely detail work with hands \\
\hline & & & Social ability & 2 & Competency to communicate with others \\
\hline & & & Cognitive ability & 2 & Competency to concentrate on work or leader \\
\hline 14 & $\begin{array}{l}\text { Management } \\
\text { system of plant }\end{array}$ & $\begin{array}{l}\text { Outdoor garden } \\
\text { management }\end{array}$ & Physical ability & 3 & Competency to deliver gardening product \\
\hline & & & Social ability & 3 & Competency to take care others \\
\hline 15 & & Final examination & & & \\
\hline
\end{tabular}

${ }_{\mathrm{z}}^{\mathrm{N}}$ : Competency Number. 
order, decrease of productivity, distraction in work attitude, difficulty in using tools, poor motion skills and lack of compliance with workplace etiquette (Jung, 2002). Therefore, for competency-based instructional design to nurture indoor gardening work capability while improving such poor competencies, the panel defined tasks relate to indoor gardening as using a tool, delivery, arrangement, caring and service. Based on the selection of cognitive, physical and social competencies by the panel as core competencies of the indoor gardening course, this study selected the capability indicators according to the core competencies as concentration, concept of numbers, ability to use a tool, ability to move and deliver, fine motor skill, coordination of eye and hand, communication skill, ability to consider others, and ability to fulfill a duty, and then came up with a 15-week competency-based instructional design as shown in Table 5. The competencies were scattered for students to repeatedly learn repeatedly learn the five fields of tasks of indoor gardening assistants in connection with the course content at least 3 times on average within 15 weeks. This implies that the design reflected the characteristics of people with developmental disabilities who can adapt only after repeated training, considering the work personality of people with developmental disabilities (Jung, 2002; Lee, 2006).

\section{Development of a competency diagnostic tool}

Evaluating the performance of indoor gardening is evaluating the performance of horticultural activities of the subjects, and previous cases show that the observation method and interview method are used (Lee et al., 2012). Here, the diagnostic tools in horticultural therapy used in Korea are mostly evaluation tools standardized for clinical psychology, medical science or other fields of humanities and social science, which are modified for horticulture. Cognitive function test and stress measurement were analyzed for cognitive function; self-esteem scale, depression scale and mono-mental state examination for mentality; daily life activity evaluation for physical competency (Kim et al., 2015); communal behavior scale and interpersonal relation scale for social competency (Kim, 2010); and other horticultural activity assessment table and horticultural work evaluation were analyzed. In this study, job competency evaluation is performed by extracting evaluation items related to indoor gardening tasks focusing on HAPA by Kim (2004) and developing them into rubric for descriptive writing that is suitable for self-diagnosis of students with developmental disabilities, thereby coming up with a diagnostic test as shown in Table 6. The score card here is drawn up after the review, revision and improvement of the panel through FGI (focus group interview) regarding whether it is appropriate for university students with disabilities. This table reflects the views of the expert panel claiming that it is more effective for improving learning motives and evaluating scholastic achievement to form competencies into rubric for descriptive writings in the form of knowledge (K), skills (S) and attitude (A) and briefly present them so that university students with developmental disabilities can understand. The US has been implementing the rubric for descriptive writing instead of scores in performance assessment for 20 years, but Korea still lacks development of an assessment tool in systematic rubric form. Therefore, to reflect the advantages of customized rubric on the evaluation of university students with developmental disabilities, the expert panel (focus group interview) went through verification steps to revise the sentences to make them easier, and implemented and reviewed plot types and completed 9 items of the diagnostic test as shown in Table 6 .

The whole framework was composed of a 5-point scale in core competencies, index of capability, learning standard and diagnostic evaluation. Core competencies are categorized into cognitive, physical and social competencies. The index of capability is based on concentration when students are lectured about the method to manage light, temperature, moisture, soil and fertilizer that are the basic knowledge for plant management as tasks of indoor gardening assistants. For learning standard, the score card was made so that the concentration on work and leader with short sentences that can be understood by students with developmental disabilities could be rated on a 5-point scale. For cognitive competency, the ability to 
Table 6. The chart of diagnosis according to instructional design based on competency.

\begin{tabular}{|c|c|c|c|}
\hline Core competency & & Index of capacity & Standard of study \\
\hline \multirow{3}{*}{$\begin{array}{l}\text { Physical } \\
\text { competency }\end{array}$} & $2^{\mathrm{w}}$ & Competency to coordination of eye and hand & $\begin{array}{l}(K)^{z} I \text { understand how to coordinate of eye and hand } \\
(S)^{y} \text { I have the skills to use hand eye coordination } \\
(A)^{x} \text { I always use hand eye coordination }\end{array}$ \\
\hline & 3 & Competency to delivery container & $\begin{array}{l}\text { (K)I understand how to deliver gardening product } \\
\text { (S)I can deliver gardening product } \\
\text { (A)I always deliver gardening product confidently }\end{array}$ \\
\hline & 1 & $\begin{array}{l}\text { Competency to perform fine muscles of arms } \\
\text { and entire body with flexibility }\end{array}$ & $\begin{array}{l}\text { (K)I understand how to work finely detail with hands } \\
\text { (S)I can use finely detail work with hands } \\
\text { (A)I use finely detail work with hands }\end{array}$ \\
\hline \multirow{3}{*}{$\begin{array}{l}\text { Cognitive } \\
\text { competency }\end{array}$} & 3 & Competency to calculate & $\begin{array}{l}\text { (K)I understand how to calculate } \\
\text { (S)I can calculate } \\
\text { (A)I always calculate }\end{array}$ \\
\hline & 1 & Competency to use horticultural tools & $\begin{array}{l}\text { (K)I understand how to use horticultural tools, } \\
\text { (S)I can use horticultural tools } \\
\text { (A)I use horticultural tools }\end{array}$ \\
\hline & 2 & Competency to concentrate on work or leader & $\begin{array}{l}\text { (K)I understand how to concentrate on work or leader } \\
\text { (S)I can concentrate on work or leader } \\
\text { (A)I always concentrate on work or leader }\end{array}$ \\
\hline \multirow{3}{*}{$\begin{array}{l}\text { Social } \\
\text { competency }\end{array}$} & 1 & Competency to cooperate with others & $\begin{array}{l}\text { (K)I understand how to cooperate with others } \\
\text { (S)I can cooperate with others } \\
\text { (A)I always cooperate with others }\end{array}$ \\
\hline & 2 & Competency to communicate with others & $\begin{array}{l}\text { (K)I understand how to communicate with others } \\
\text { (S)I can communicate with others } \\
\text { (A)I always communicate with others }\end{array}$ \\
\hline & 3 & Competency to take care others & $\begin{array}{l}\text { (K)I understand how to take care others } \\
\text { (S)I can take care of others } \\
\text { (A)I always take care others }\end{array}$ \\
\hline
\end{tabular}

${ }^{\mathrm{z}} \mathrm{K}$ : Knowledg, ${ }^{\mathrm{y}} \mathrm{S}:$ Skill, ${ }^{\mathrm{x}} \mathrm{A}$ : Attitude, ${ }^{\mathrm{w}}$ Competency Number.

concentrate and use a tool was set as the evaluation index. Moreover, for concept of numbers, taking measurements and comparing sizes or continuously counting numbers during horticultural activities were set as the index. For physical competency, the index consisted of the ability to move plants, coordination of eye and hand when spraying water on designated areas, using a tool to cut materials or using fine motor skill, which is an evaluation of indoor gardening work performance in the same perspective as Kim (2016) and Kim (2004). Furthermore, by selecting the ability to complete one's duty in collaboration, ability to communicate and ability to consider others as items to evaluate social competency through the verification of an expert panel, it can be found that the detailed items of social competency verified by Kim (2016), Lee (2006) and Song (2004) are verified as key indicators of tasks of indoor gardening assistants as well. 


\section{Competency diagnostic analysis}

\section{1) General characteristics of research subjects}

Among students with developmental disabilities attending K University, 20 students were selected as the experimental group participating in the competency-based indoor gardening course, and other 20 students as the control group. The students are all in the same department of the same university, 31 male and 9 female students all in the department specialized in developmental disabilities. To statistically compare the competency improvement evaluation according to the participation in the indoor gardening course, a homogeneity test was conducted. As a result, Table 7 shows no significant difference in cognitive, physical and social competencies in both groups, thereby verifying homogeneity of the two groups.

\section{2) Analysis of competency improvement before and after the course}

The difference in competencies before and after the course was compared by the test of competency diagnosis. To verify the validity of the test of competency diagnosis of university students with developmental disabilities, it was verified by the expert panel and performed after proving reliability of 0.859 based on Cronbach's $\alpha$ test. The test results showed that cognitive competency increased from $1.80 \pm 0.12$ points to $3.96 \pm 0.147$ points after the experiment in the experimental group, and physical competency increased from $1.86 \pm 0.12$ points to $4.06 \pm 0.18$ points, showing statistically significant results. Social competency increased from $2.30 \pm 0.12$ points to $4.40 \pm 0.17$ points, showing statistical significance. On the other hand, in the control group, social competency increased from $2.86 \pm 0.11$ points to $2.9 \pm 0.12$ points but showed no statistical significance. Cognitive competency also did not show statistically significant results, and only physical competency showed statistically significant results (Table 8). In other words, through the indoor gardening course, only

Table 7. Result of equivalence check.

\begin{tabular}{lcccc}
\hline \multicolumn{1}{c}{ Item } & Control & Treatment & $\mathrm{t}$ & $p$ \\
\hline Cognitive competency & $3.76 \pm 0.14^{\mathrm{z}}$ & $4.56 \pm 1.37$ & -.579 & $0.500^{\mathrm{NS}}$ \\
Physical competency & $3.7 \pm 0.17$ & $3.4 \pm 0.17$ & 1.492 & $0.141^{\mathrm{NS}}$ \\
Social competency & $3.9 \pm 0.18$ & $3.4 \pm 0.20$ & 1.790 & $0.079^{\mathrm{NS}}$ \\
\hline
\end{tabular}

${ }^{\mathrm{z}}$ Mean \pm SD.

${ }^{\mathrm{NS}}$ Nonsignificant.

Table 8. Paired T test for before and afterthe course according to instructional design.

\begin{tabular}{ccccc}
\hline \multirow{2}{*}{ Item } & Group & \multicolumn{3}{c}{ Treatment } \\
\cline { 3 - 4 } & & Before & After \\
\hline \multirow{2}{*}{ Cognitive competency } & Control & $1.93 \pm 0.10^{\mathrm{z}}$ & $3.03 \pm 0.16$ & $0.140^{\mathrm{NS}}$ \\
& Treatment & $1.80 \pm 0.12$ & $3.96 \pm 0.147$ & $0.000^{* * *}$ \\
Physical competency & Control & $2.5 \pm 0.10$ & $3.10 \pm 0.11$ & $0.000^{* * * *}$ \\
& Treatment & $1.86 \pm 0.12$ & $4.06 \pm 0.18$ & $0.000^{* * *}$ \\
Social competency & Control & $2.86 \pm 0.11$ & $2.9 \pm 0.12$ & $0.801^{\mathrm{NS}}$ \\
& Treatment & $2.30 \pm 0.12$ & $4.40 \pm 0.17$ & $0.000^{* * *}$ \\
\hline
\end{tabular}

\footnotetext{
${ }^{\mathrm{z}} \mathrm{Mean} \pm \mathrm{SD}$.

${ }^{\mathrm{NS}}$ Nonsignificant, ${ }^{* * *} p<.001$.
} 
the experimental group showed a significant improvement in all three fields - cognitive, physical and social competencies - for job competency. Thus, compared to the control group, competency-based instructional design has evenly affected the increase of competency of university students with disabilities regarding tasks of indoor gardening assistants. Furthermore, the remarkable increase of social competency indicates that competency-based indoor gardening course is a job-related course that can improve sociality, which is most lacked by students with developmental disabilities as proved by Kim (2016) and Oh (2003). Accordingly, it can contribute to improving social competency that is the basic quality for various assistive tasks mostly performed by people with developmental disabilities aside from indoor gardening assistants. In other words, through the indoor gardening course that can enhance the practical competencies of indoor gardening assistants, the competency diagnostic evaluation and instructional method of diagnosing and providing feedback on changes in the ability to communicate, fulfill duties and consider others have actually been proved as effective for improving job performance in the actual field.

\section{Conclusion}

This study was conducted to establish a competency-based instructional design and competency diagnostic tool so that the indoor gardening course can secure its place as a regular curriculum for university students with developmental disabilities in higher education.

In Step 1, an expert panel was organized regarding competency-based horticultural education to design a competencybased indoor gardening course. In Step 2, the expert panel went through DACUM meetings to review the fields that can be associated with tasks, defined the tasks of indoor gardening assistants, and designed the necessary core competencies and capability indicators as well as learning standard. In Step 3, a competency diagnostic test was developed. In step 4 and 5 the test was conducted on university students with developmental disabilities before and after the course, and the results were analyzed. The effects of competency-based instructional design on the improvement of job performance for university students with developmental disabilities were analyzed as the paradigm has shifted in recent university curriculum into a more realistic goal of fulfilling job performance capabilities, thereby revealing that the indoor gardening course can be used as a job-related knowledge course that is meaningful in university education for students with developmental disabilities. Furthermore, a pretest and posttest were performed to analyze the contribution of horticultural class to job competency improvement, and as a result, social competency showed high improvement. Accordingly, the indoor gardening course that improves social competency that is most lacked by students with developmental disabilities actually contributes to improving job performance of indoor gardening assistant. This may be because social competency set in this study consists of considering others, fulfilling duties and communicating, and is thus a field necessary for all jobs of people with developmental disabilities. Therefore, a competency-based indoor gardening course design can not only improve job performance of university students with developmental disabilities but also be used as a course for vocational rehabilitation.

\section{References}

Jung, H.J. 2002. Effect of horticultural therapy on the changes of self esteem and anxiety of the mentally retarded students in high school. MS thesis, Konkuk Univ., Seoul, Korea.

Kang, J.H. 2005. Special Education. Seoul, Korea:Heeso.

Kang, S.J. 2002. Evaluation of the effects of horticultural therapy on physical ability in elderly people. MS thesis, Yonsei 
Univ., Seoul, Korea.

Kim, H.S., S.R. Ahn, H.J. Juan, and J.O. Kang. 2002. Standard development for making questions of national technical qualification through the DACUM method. J. Vocat. Educ. Res. 21(1):9-28.

Kim, N.E. 2004. Development of horticultural activity performance assessment for mild and moderate mentally retarded people. MS thesis, Konkuk Univ., Seoul, Korea.

Kim, S.Y. 2016. Development of competency-based horticulture rehabilitation assistant curriculum for disability university students. J. Korean Soc. People Plants Environ. 19(6):595-604 DOI: 10.11628/ksppe.2016.19.6.595

Kim, S.Y. 2010. Job analysis of horticultural therapist using DACUM and design of competency-based curriculum. $\mathrm{PhD}$ Diss., Konkuk Univ., Seoul, Korea.

Kim, S.Y., S.A. Park, K.C. Son, and C. Lee. 2014. Horticultural therapy: Job analysis, performance evaluation, and educational needs. Korea J. Hort. Sci. Tech. 32(6):887-900. DOI: 10.7235/hort.2014.14110

Kim, S.Y., S.A. Park, K.C. Son, and C. Lee. 2015. Designing of competency-based curriculum for Korean horticultural therapist. J. Korean Soc. People Plants Environ. 18(3): 169-179 DOI:10.11628/ksppe.2015.18.3.169

Lee, S.J., S.M. Lee and J.K. Suh. 2012. The conceptual frame of horticultural therapy as vocational training for adolescents with intellectual disabilities. J. Korean Soc. People Plants Environ. 15(5):307-318.

Lee, S.J. 2007. Effect of horticultural therapy using the floral decoration training on the improvement of occupational performance ability and vacational rehabilitation in mentally retarded. MS thesis, Konkuk University, Seoul, Korea.

Lee, S.S. 2006. Approach to rehabilitative horticulture therapy based on motion analysis of flower arrangement. PhD. Diss., Konkuk University, Seoul, Korea.

Oh, G.S. 2003. The problems and a reform measure in vocational education at the special schools for students with developmental disabilities from vocational rehabilitation perspective. J. Spec. Educ. 38(3):99-131.

Song, J.E. 2004. Effect of the horticultural therapy on life functional skills and vocational achievement of students with mental retardation. PhD. Diss., Daegu University. Gyungbook. 